桨 (C) National Association for Business Economics

\title{
Federal Reserve Independence in the Aftermath of the Financial Crisis: Should We Be Worried?
}

\section{DONALD KOHN*}

The extraordinary circumstances of the past few years have led to extraordinary responses by the Federal Reserve and other central banks. These ventures into uncharted waters have heightened political scrutiny to the point of raising concern about future independence. In discussing independence of the Federal Reserve, it is important to separate its regulatory and supervisory functions from its monetary policy function. It is the latter in which the question of independence is most important. History indicates that independent monetary policy has been a powerful deterrent to inflation. This paper outlines the threats to Federal Reserve independence, particularly as it exists from the unconventional policies that it pursued to mitigate the financial crisis. Economists have an important role in making the case that monetary policy remains independent.

Business Economics (2013) 48, 104-107.

doi:10.1057/be.2013.1

Keywords: Federal Reserve, monetary policy, independence, financial crisis, scrutiny

$W$ e are going through an extraordinary period in business cycles and central banking. The too-calm, too-confident, veneer of the so-called Great Moderation was shattered by the worst financial crisis in 80 years. The Federal Reserve, indeed central banks all over the industrial world, have taken extraordinary actions to make sure that this crisis is not followed by an economic result like that of the 1930s.
The Federal Reserve expanded access to the discount window for banks, and it opened credit facilities to nonbanks for the first time since the 1930s - including, in a few cases, helping to stabilize or facilitate the takeover of systemically important institutions that were at risk and whose failure would have further destabilized the financial system. The Federal Reserve aggressively reduced short-term rates to zero and then, to spur growth, worked to reduce intermediate- and long-term rates even further by greatly expanding its balance sheet with purchases of long-term securities and by issuing guidance about the future path of short-term rates. And it has addressed perceived clogs in the transmission of monetary policy by intervening directly in the government guaranteed mortgage market - taking a hand in credit allocation where markets are not functioning well. Other central banks in industrial countries that have been hit by crisis in recent years have taken comparable, unconventional, steps to stabilize markets and encourage growth. We are in uncharted territoryboth in our understanding of economic developments and of the policy response.

\section{Independence and the Functions of the Federal Reserve}

Naturally, understandably, and appropriately, these circumstances have increased the scrutiny of central banks, including the Federal Reserve, raising questions about the goals, governance and accountability of these institutions. This panel has been asked whether we should be worried that this scrutiny will result in an erosion of independence. To foreshadow my answer: the extreme steps taken by central banks in response to the crisis should

Comments for a Panel of the National Association for Business Economics at the American Economic Association Annual Meetings, January 2013.

*Donald Kohn is a senior fellow at the Brookings Institution and an external member of the Financial Policy Committee at the Bank of England. He served on the staff of the Federal Reserve Board from 1975 to 2002 and on the Board of Governors of the Federal Reserve from 2002 to 2010, the last four years as vice chairman. He holds a B.A. (Economics) from The College of Wooster and a Ph.D. (Economics) from the University of Michigan. 
not and need not lead to a loss of monetary policy independence, but we need to be vigilant because the number and magnitude of risk factors have increased.

When discussing central bank independence, it is important to draw two key distinctions about what we mean. The first distinction concerns functions performed by the central bank. With regard to independence, our main focus has been on the setting of monetary policy, not regulatory policy. In this regard, the Federal Reserve has always lived with a bifurcated regime. The regulatory functions of the Federal Reserve have involved a very high degree of cooperation and coordination with other agencies. Major decisions are arrived at jointly by several agencies. And those decisions are subject to examination and oversight by the General Accountability Office of the Congress.

The cooperative character of bank regulation is made necessary by the balkanized U.S. regulatory system, with many different agencies having a hand in regulation and supervision of the financial system. It also reflects the nature of the actions taken. Regulation is necessary to offset the moral hazard created by the safety net available to financial institutions and to deal with externalities. But it involves elements of credit allocation, it constrains private decisions, and it affects the relative positions of individual firms. And it can have consequences for the public purse if regulation and supervision are not effective enough at constraining risk. Some degree of independence from political pressure is helpful in carrying out these tasks, but they may not lend themselves to the same arm's length relationship to elected representatives as does monetary policy.

The conduct of monetary policy has enjoyed considerably more, but still limited, independence. Within monetary policy, it is useful to distinguish goal from instrument independence. Goals for policy are and should be set in the democratic process by elected representatives. But independence is critical in the setting of the instruments to achieve these goals. Central banks should be held accountable for outcomes, not inputs. Instrument independence is necessary to overcome the short-term perspective of politicians, who are more interested in boosting growth for the next election and less focused on the longerterm inflationary consequences of such actions. Across time and countries there is plenty of evidence that less independence is correlated with higher inflation.
Even instrument independence is not absolute. Instrument settings will always be subject to political pressure and discussion. Moreover, some control is exercised through the appointments process, which for the Chairman occurs every four years. Nonetheless, an independent central bank-one that has been insulated from these pressures - does not need to follow the politicians' instructions; it should resist where those desires are inconsistent with its own views of how to achieve the objectives it has been given.

\section{Threats to Federal Reserve Independence}

In considering whether Federal Reserve independence is likely to be threatened by the nature and aggressive character of its recent actions, it is important to keep in mind that there is no necessary connection between recent actions and future loss of independence. This is a decision for Congress to make legislatively, and it needs to understand the costs and benefits of any erosion of independence. Moreover, concern about a potential mistake by Congress in this regard is not a reason for the Federal Reserve to hold back on using the tools Congress has given it to accomplish the objectives Congress has set. The Federal Reserve needs to keep explaining why it considers its actions to have been consistent with furthering its objectives. It must explain that any fiscal risk incurred or credit allocation affected by its actions has been necessary to achieve its legislated objectives and that these actions have been a temporary function of an extraordinary situation. We can see from what is going on in Japan right now that perceptions of timidity and caution also have the potential to threaten independence.

But a number of risk factors suggest that extra vigilance will be called for over coming years to preserve the appropriate degree of Federal Reserve independence. First, an era of polarization of political discourse has not proven conducive to a reasoned discussion of monetary policy and the pros and cons of independence. Exhibit 1 in this regard would be the debates in the Republican primaries in which candidates competed as to how rapidly they would "fire" Ben Bernanke, with one characterizing a policy disagreement as "almost treasonable". Also discouraging was the unprecedented letter from Republican congressional leaders to the Federal Reserve in September 2011 trying to dictate an instrument setting - the management of its portfolio. And, as I will underline 
in a second, we have not yet heard from the forces that might eventually be aroused by exit from its recent extraordinary policies.

Second, the Federal Reserve has had some powers trimmed in the Dodd-Frank Wall Street Reform and Consumer Protection Act, suggesting an erosion of trust and deference by lawmakers. The restrictions apply to its authority to lend to nonbank institutions under 13-3 of the Federal Reserve Act and include an obligation to get the approval of the Secretary of the Treasury, even for widely available facilities. In addition, against the recommendation of the Federal Reserve, the Congress mandated the publication of the names of all borrowers at the discount window-bank and nonbank - no later than two years after they borrow. So far, the instrument independence of the Federal Reserve in monetary policy has not been abridged in any way, but it may be that the Federal Reserve's views carry less weight than they did before the crisis.

Third, although in recent years the political blowback mainly has come from those who say they are worried about inflation, the major challenge to independence is likely to come from those concerned about unemployment as the Federal Reserve exits from unconventional policies. At some point, the Federal Reserve will need to tighten policy to keep inflation from rising persistently above its price stability target. It will need to raise rates and begin returning its portfolio toward its prior plain vanilla size and composition. The turn toward tightening is always a difficult decision-and subject to second-guessing in the political sphere-but it will be even tougher after a long period of weak growth and unprecedented policy actions.

It will be a complex exit involving many stepswith lots of opportunity for kibitzing and objecting over a long period. It will ultimately involve a sharp correction in long-term rates - a reversal of a negative term premium as well as upward adjustment in expected short-term rates. It will entail withdrawal of special support for the mortgage market. As long-term rates rise, the Federal Reserve will have mark to market losses on its balance sheet. These losses are not a threat to the Federal Reserve's ability to tighten or its independence so long as cash flow is positive, but the losses could be used as a political weapon. The main tightening tool will be increases in the interest rate paid to banks on their deposits at the Federal Reserve, further damping Federal
Reserve profits; this is a tool well known in other jurisdictions, but is new for the United States. The size of the portfolio should not impede ability to tighten, given this new tool; but a huge volume of reserves could make control over the federal funds rate less precise than it has been in the past. Finally, in light of the apparent inability of the Congress and administration to deal with longer-term budget issues, the rise in rates could be occurring in the context of a still-unsustainable path for budget and debt; and higher rates will underline that issue and make it worse. This will be another source of unhappiness in the political sphere.

Fourth, the Federal Reserve, like many other central banks, has been given added responsibilities in regulation and supervision. These responsibilities include a key role in macroprudential regulation, with responsibility for protecting the overall stability of the financial system. Carrying out this regulation already involves a differential impact on some organizations - those identified as systemically important. It could also entail tightening up when credit is growing too fast and imbalances are seen to be developing-another form of taking away the punch bowl as the party gets going. An example would be raising the countercyclical capital buffer under Basel III. This will not be popular with those drinking the punch. In the years leading up to the crisis we saw considerable political resistance to even mild forms of tighter policy, for example with respect to commercial real estate lending. The risk is that greater scrutiny and criticism of this aspect of Federal Reserve activity could spill over to monetary policy. It is important to retain the bifurcation - the differences between governance and accountability for regulation on the one hand and monetary policy on the other.

But macroprudential policy could also protect monetary policy independence. It reduces the need for the Federal Reserve to use monetary policy to deal with bubbles, imbalances, or a build up of leverage. It now has another tool to apply to these. Monetary policy can be focused on price stability and maximum employment and more readily held accountable for those less diffuse goals than for "financial stability". More focused goals and accountability should support retaining monetary policy independence.

The most immediate threat to appropriate independence now would seem to be the proposal to allow the Government Accountability Office 
(GAO) to audit monetary policy - to remove the exemption for monetary policy that has existed since the 1970s. The expanded GAO audit authority would be another avenue to bring pressure on the Federal Reserve's monetary policy-perhaps trying to delay actions pending a GAO study. Of course, such pressure can and should be ignored when the Federal Reserve is convinced it is doing the right thing to accomplish its legislated objectives. But extending the GAO audit moves the needle, however slightly, in the wrong direction when it will be important to protect the Federal Reserve's instrument independence for exit from its current positions. And it erodes that distinction between the governance of regulatory and monetary policy functions that seems so useful to make.

\section{Conclusion}

It will be critical to preserve Federal Reserve monetary policy independence over the next few years. There is just too much history behind the concern that less independence leads to higher inflation over time. I hope all economists can agree on this - whatever they think of the actual policy actions that have been undertaken. The views of economists could be important in any discussion of monetary policy independence that might occur. 